\title{
Sistem Tanya Jawab Konsultasi Shalat Berbasis RASA Natural Language Understanding (NLU)
}

\author{
Muhammad Rizqi Sholahuddin ${ }^{1}$, Firas Atqiya ${ }^{2}$ \\ 1) Jurusan Teknik Komputer Informatika, Politeknik Negeri Bandung \\ Jl. Gegerkalong Hilir, Ciwaruga, Kec. Parongpong, Kabupaten Bandung Barat, Jawa Barat 40559 \\ Email: muhammad.rizqi@polban.ac.id \\ 2) Prodi Teknik Informatika, Fakultas Sains dan Teknologi, Universitas Muhammadiyah Bandung \\ Jl. Soekarno-Hatta No.752, Cipadung Kidul, Kec. Panyileukan, Kota Bandung, Jawa Barat 40614 \\ Email: firasatqiya@umbandung.ac.id
}

\begin{abstract}
ABSTRAK
Chatbot merupakan sistem cerdas yang memberikan pengalaman kepada user berupa interaksi langsung dengan mesin melalui media tulisan. Paper ini memaparkan penggunaan chatbot sebagai saranan tanya jawab seputar tata cara shalat. Seorang muslim ada kalanya memiliki pertanyaan mengenai tata shalat ketika menemukan adanya perbedaan antara tata cara yang dilakukannya dengan tata cara yang dilakukan muslim lainnya. Pemanfaatan chatbot dalam hal ini adalah untuk menyediakan jawaban mengenai hal tersebut. Chatbot ini dikembangkan dengan model deep learning, khususnya LSTM yang sudah terintegrasi dengan RASA framework. LSTM (Long Short Term Memory) secara efisien dapat menghemat beberapa memori yang diperlukan, namun juga akan menghapus beberapa memori yang tidak diperlukan. Platform telegram dipilih untuk implementasi chatbot ini. Hasil penelitian menunjukkan bahawa chabot telegram konsultasi shalat dengan DIET Classifier dan RASA mampu mengenali pertanyaan dan memberikan respon dalam bentuk teks dan gambar, untuk hasil akurasi didapatkan $96 \%$.
\end{abstract}

Kata kunci: chatbot, NLU, RASA, shalat

\begin{abstract}
A chatbot is an intelligent system that provides users with direct interaction with machines via written media. This paper describes how to use chatbots to ask questions about prayer procedures. A Muslim sometimes has questions about the procedure for praying when he finds a difference between the procedures performed by other Muslims. In this case, the use of chatbots is to provide an explanation. This chatbot was developed using a deep learning model, especially LSTM, that was integrated with the RASA framework. LSTM (Long Short Term Memory) can efficiently save some of the needed memory while also removing some of the unnecessary memory. The Telegram platform was chosen for the chatbot's implementation. The results showed that the chatbot telegram prayer consultation with DIET Classifier and RASA was able to recognize questions and provide answers in the form of text and images, with 96 percent accuracy.
\end{abstract}

Keywords: chatbot, NLU, RASA, Salat

\section{Pendahuluan}

Shalat merupakan ibadah wajib bagi umat muslim, namun terkadang terdapat perbedaan tata cara shalat yang mengakibatkan timbulnya pertanyaan di kalangan umat muslim sendiri. Seyogianya pertanyaan tersebut ditanyakan kepada seorang ahli, seperti kyai atau ustadz(ah), sehingga komunikasi terjalin secara interaktif. Akan tetapi tidak semua muslim memiliki akses langsung untuk bertanya langsung kepada para ahli sehingga mencari jawaban atas pertanyaan terkait shalat dilakukan dengan penelusuran di internet. Namun, hasil penelusuran melalui internet menampilkan banyak jawaban yang membuat pengguna harus memilah kembali jawaban yang tersedia. Akibatnya, pencarian jawaban atas sebuah pertanyaan memakan waktu lama dan tidak praktis. Sebagai solusi atas kondisi tersebut, peneliti membangun chatbot interaktif yang berfokus pada tata cara shalat.

Chatbot sendiri adalah salah satu sistem cerdas yang menerapkan Natural Language Processing (NLP) dalam prosesnya. Chatbot memberikan pengalaman kepada user berupa interaksi langsung dengan mesin melalui media tulisan (text). Bahasa adalah timbal balik sosial dan budaya untuk protokol alami. Sudah saatnya mesin komputer menambahkan fitur untuk memahami manusia seiring dengan peningkatan kinerja perangkat keras mesin komputer baru-baru ini [1]. 
Penelitian yang menghasilkan luaran aplikasi yang interaktif telah banyak dipublikasikan, misalnya saja di bidang pendidikan telah dikembangkan media pembelajaran interaktif untuk mendukung pembelajaran jarak jauh [2], selain itu di bidang pelestarian budaya dan sejarah telah dirancangan game tradisional "tambah satu" berbasis android [3] dan game untuk mengenalkan tokoh pahlawan Indonesia kepada generasi Z [4]. Penelitian yang menghasilkan chatbot sebagai luaran penelitian juga sudah dipublikasikan, baik itu di bidang pendidikan, pariwisata, medis dan bidang lainnya. Sebagai contoh adalah penelitian yang menghasilkan chatbot untuk memfaslitasi interaksi antara mahasiswa/i dengan pihak fakultas terkait proses akademik [5]. Penelitian lainnya menghasilkan chatbot untuk menyediakan informasi terkait objek wisata di kota Bandung [6], juga chatbot untuk membantu proses transaksi penjualan UMKM [7]. Selain itu, ada pula penelitian untuk membangun model sistem tanya jawab medis berbasis case-based reasoning [8].

Case Based Reasoning (CBR) adalah menggunakan pengalaman yang telah ada untuk memahami dan menyelesaikan permasalahn baru. Pada CBR, solusi permasalahan ditentukan dengan mencari situasi lalu yang mirip dengan masalah yang sedang dihadapi kemudian menerapkan solusi tersebut. Secara sederhana, CBR dapat dipahami sebagai teknik untuk menentukan solusi sebuah permasalahan dengan mengadaptasi solusi-solusi permasalah yang mirip dan pernah ada sebelumnya [9].

Tujuan penelitian ini, menghasilkan chatbot yang dapat digunakan sebagai sarana konsultasi mengenai tata cara sholat. Hal ini diperlukan karena akan membantu pengguna untuk mendapatkan jawaban terkait tata cara sholat tanpa harus melakukan pencarian panjang melalui internet sehingga waktu yang diperlukan menjadi lebih singkat.

\section{Metode Penelitian}

Penelitian menggunakan metode kuantitatif, yang terdiri dari pengujian accuracy, precision, dan recall. Adapun tahapan penelitian dapat dilihat pada Gambar. 1.

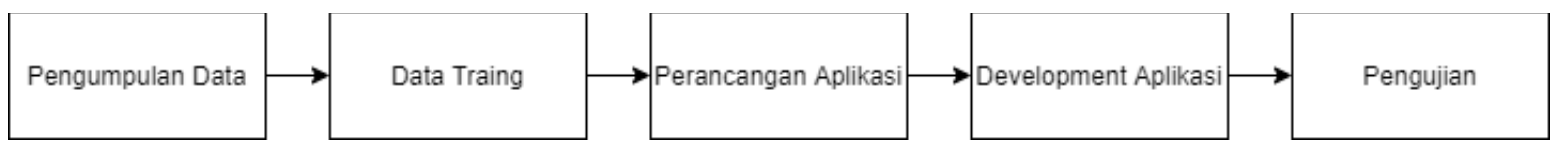

Gambar 1. Tahapan penelitian

Penelitian dimulai dengan pengumpulan data. Pada tahap ini data dikumpulkan dari dari buku dan situs tanya jawab konsultasi sholat. Kemudian dilakukan proses prepocessing yang bertujuan untuk melihat pola pertanyaan, luaran tahap ini adalah dataset pertanyaan dan jawaban terkait konsultasi sholat. Pada proses preprocessing sendiri yang dilakukan adalah klasifikasi maksud (intent classification) dan ekstraksi entitas (entity extraction) dari setiap kalimat.

Tahap berikutnya adalah pelatihan data. Pada tahap ini dataset hasil prepocessing pada tahap sebelumnya akan menjadi input.

Setelah proses training selesai, lalu dilanjutkan dengan tahap perancangan sistem. Kemudian dilanjutkan dengan tahap pembangunan aplikasi. Lalu yang terkahir adalah tahap pengujian sistem. Pada tahap terakhir ini pengujian yang dilakukan adalah pengujian data yang dapat masuk ke server chat.

\section{Tinjauan Pustaka}

\section{Natural Language Processing}

Natural Language Processing (NLP) adalah bidang keilmuan yang mempelajari bagaimana komputer atau mesin dapat digunakan untuk memahami dan memanipulasi bahasa natural baik yang berupa tulisan (text) atau suara (speech) [10]. Tujuan dari bidang NLP adalah untuk membuat desain dan membangun aplikasi yang dapat memfasilitasi interaksi antara manusia dan mesin atau perangkat lainnya dengan menggunakan bahasa natural [11]. Bahasa natural adalah bahasa yang biasa digunakan oleh manusia untuk saling berkomunikasi. Beberapa area utama dalam bidang NLP diantaranya adalah Question Answering Systems (QAS), Summarization, Machine Translation, Speech Recognition, dan Document Classification [11]. 


\section{Chatbot}

Chatbot adalah salah satu sistem cerdas yang menerapkan Natural Language Processing (NLP) dalam prosesnya. Chatbot memungkinkan terjadinya komunikasi antara manusia dan mesin dengan menggunakan tulisan (text). Pada dasarnya bot memulai proses dengan melihat kata kunci dalam setiap data yang masuk dan kemudian memberikan balasan dengan kata kunci yang paling sesuai, atau pola rangkaian kata yang paling mirip dari basis data tekstual yang telah dibuat. Hal ini berarti apabila pengguna memasukkan sebuah permintaan, maka bot akan memberikan balasan dengan respon spesifik sesuai dengan kata kunci yang dimasukkan oleh pengguna tersebut.

Perkembangan perangkat teknologi informasi saat ini menjadi salah satu pendukukung perkembangan aplikasi chatbot. Penerapan chatbot ada yang diarahkan untuk menjadi asisten dari penggunanya, misalnya saja chatbot yang digunakan untuk memberikan layanan customer service 24 jam. Selain itu, chatbot juga dapat dijadikan pendukung layanan Frequently Ask Question (FAQ) [5]. Dalam penelitian ini, chatbot akan digunakan sebagai sarana konsultasi mengenai tata cara sholat.

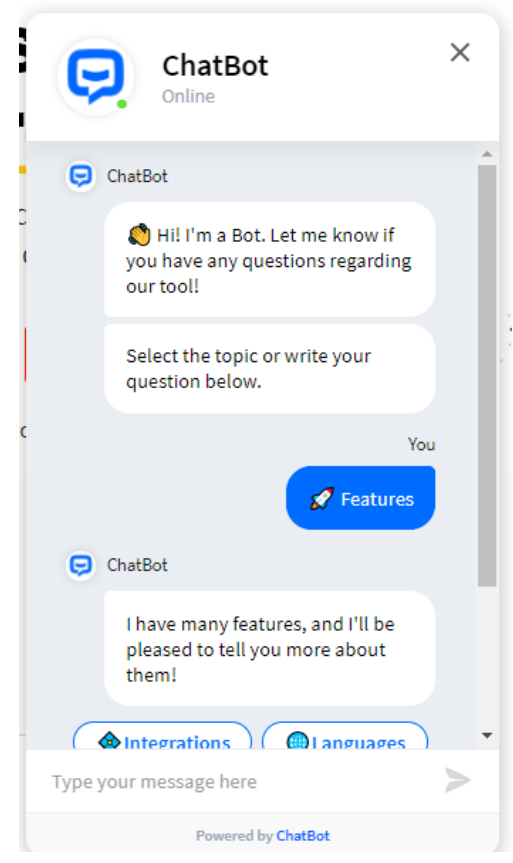

(https://www.chatbot.com/)

Gambar 2. Contoh percakapan melalui chatbot

\section{Case Based Reasoning}

Case based reasoning berarti menggunakan rekaman pengalaman yang ada untuk memahami dan menyelesaikan permasalah baru. Di dalam CBR, solusi dari rekaman kejadian lampau yang memiliki kemiripan dengan masalah baru yang sedang dihadapi akan digunakan sebagai solusi dari masalah yang sedang dihadapi saat ini. [8]

Pada CBR terdapat empat siklus utama yaitu retrieve, reuse, revise dan retain. Retrieve adalah proses pengambilan kasus paling serupa. Pada penelitian ini direncakan berdasarkan kemiripan fitur bag-of-word. Reuse adalah tahap mengambil jawaban yang paling mirip atau akurat pada dataset. Revise adalah proses revisi bisa pengurangan atau penambahan pengetahuan baru pada dataset. Tahap retain adalah proses memasukan hasil revise ke dalam dataset.

\section{Artificial Intelligence Markup Language}

Artificial Intelligence Markup Language (AIML) [12] merupakan turunan dari Extensible Markup Languange (XML). AIML memiliki kelas objek data yang menggambarkan perilaku program computer yang memrosesnya. AIML terdiri dari tag atau unit yang disebut topik dan kategori. Pada AIML, kategori adalah 
unit dasar dari pengetahuan. Setiap Kategori terdiri dari pola yang mengandung input dan template yang berisi jawaban dari chatbot.

\section{Natural Language Understanding (NLU)}

Natural Language Understanding (NLU) adalah subbidang dari pemrosesan bahasa alami yang berhubungan dengan machine reading comprehension. Tujuan dari sistem NLU adalah untuk menginterpretasikan sebuah fragmen teks input [13]. NLU akan mengesktrak informasi dari sebuah pesan. Informasi yang diekstrak adalah intent dan entity

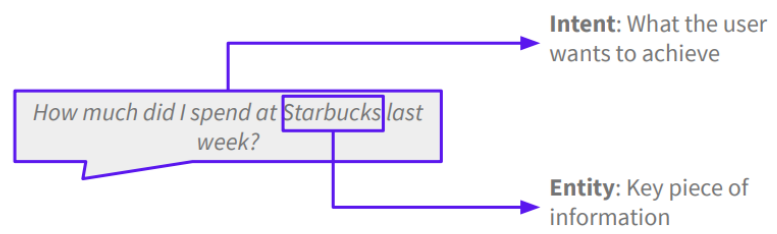

Gambar 3. Contoh informasi hasil ekstrak dari NLU

\section{Long Short-Term Memory (LSTM)}

Long Short-Term Memory (LSTM) merupakan pengembangan dari RNN yang diperkenalkan oleh Hochreiter \& Schmidhuber. LSTM dirancang secara eksplisit untuk menghindari masalah ketergantungan jangka panjang [14]. Pada LSTM, telah dilakukan modifikasi terhadap RNN dengan menambahkan memory cell yang dapat menyimpan informasi untuk jangka waktu yang lama [15].

\section{Rasa}

Rasa adalah sebuah framework machine learning bersifat open-source yang digunakan untuk mengotomatisasi teks dan percakapan berbasis suara [16]. Rasa menyediakan infrastruktur untuk membangun chatbot dan asisten virtual berbasis AI . RASA memiliki dua modul utama, yaitu Rasa NLU dan Rasa Core.

Rasa NLU adalah alat pengolah bahasa alami yang digunakan untuk klasifikasi maksud (intent classification) dan ekstraksi entitas (entity extraction) dari sebuah percakapan. Pada dasarnya Rasa NLU berperan untuk menginterpretasikan pesan. [16]

Rasa Core adalah sebuah chatbots framework untuk menangani percakapan kontekstual. Berperan untuk memprediksi dialog atau jawaban berdasarkan pada pesan sebelumnya yang dikirimkan oleh pengguna.

\section{DIET Classifier}

Dual Intent and Entity Transformer (DIET) Classifier merupakan arsitektur fleksibel yang dapat menangani proses intent classification dan proses pengenalan entitas secara bersamaan. DIET Classifier memiliki performa yang tinggi meskipun dataset yang digunakan sederhana [17]. Selain itu, DIET menyediakan kemampuan untuk plug and play berbagai embeddings pra-terlatih seperti BERT, GloVe, ConveRT, dan sebagainya. [16]

\section{Implementasi dan Hasil}

Tahap pengumpulan data menghasilkan luaran berupa dataset pertanyaan dan jawaban. Gambar 4 adalah contoh dataset yang dihasilkan.

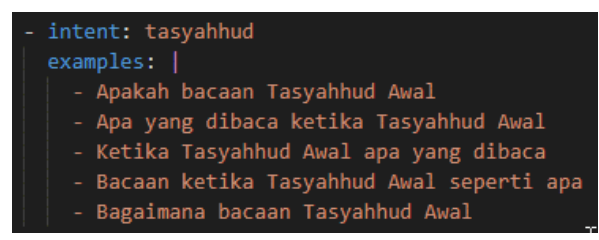




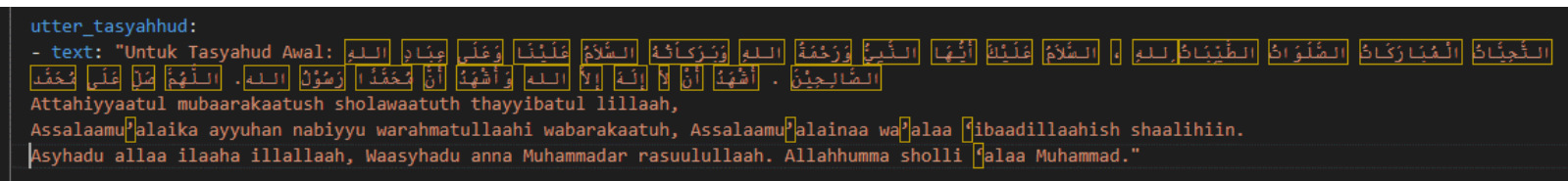

Gambar 4. Format dalam dataset

Pada rasa secara default dataset pertanyaan di simpan pada data/nlu.yml, dengan format sebagai berikut.

Intent: <Nama_Intent>

Examples:

-Pertanyaan 1 yang sesuai intent

-Pertanyaan 2 yang sesuai intent

-dst

Sedangkan untuk dataset balasan atau jawaban, di simpan pada domain.yml, dengan format sebagai berikut:

utter_<nama_intent>:

-text: (format balasan pesan)

image: (link alamat citra)

Selanjutnya adalah tahap pelatihan data. Data training yang digunakan sebanyak 58 pertanyaan. Dari 58 pertanyaan tersebut menghasilkan 15 intent, dengan komposisi training 38 dan validasi 20 pertanyaan. Gambar 5 menunjukkan status data training.

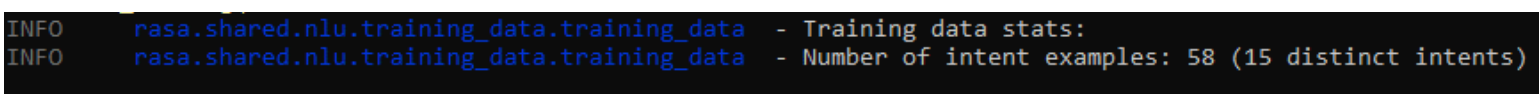

Gambar 5. Status data training

Tahap berikutnya adalah perancangan sistem. Arsitektur dari sistem yang dibangun ditunjukkan pada Gambar 6.

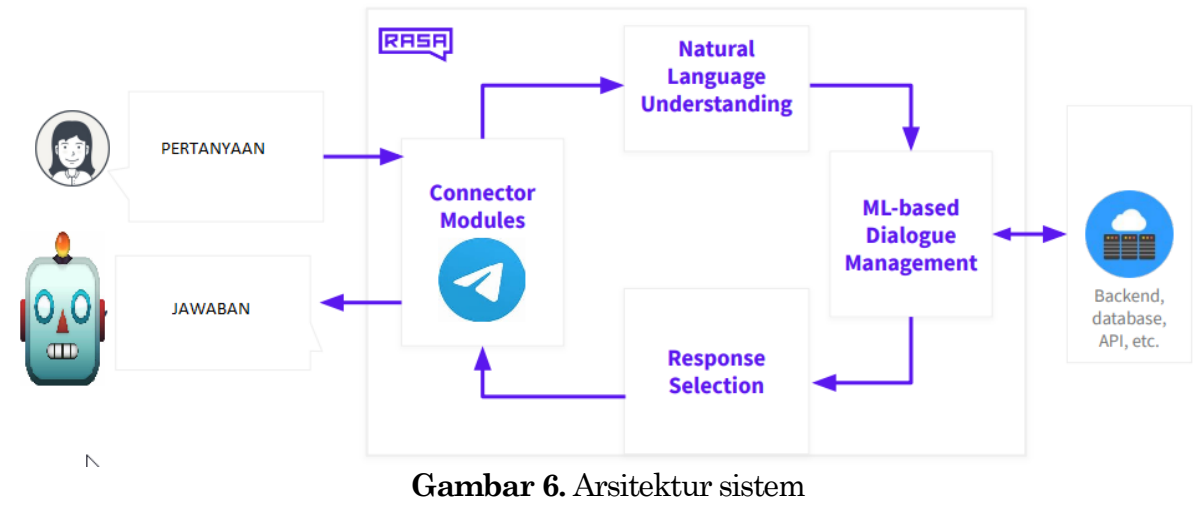

Penjelasan untuk arsitektur yang digunakan adalah sebagai berikut:

1. User dapat mengakses aplikasi melalui Telegram Desktop atau Telegram Mobile

2. User meng-input data pada berupa pertanyaan terkait sholat.

3. Sistem dengan menggunakan DIET Classifier dan NLU untuk mengklasifikasikan pertanyaan.

4. Sistem akan memberikan output kepada user berupa jawaban

Setelah perancangan sistem, selanjutnya adalah tahap pembangunan aplikasi, Pada Gambar 7 ditunjukkan tampilan awal aplikasi yang sudah dibangun. 


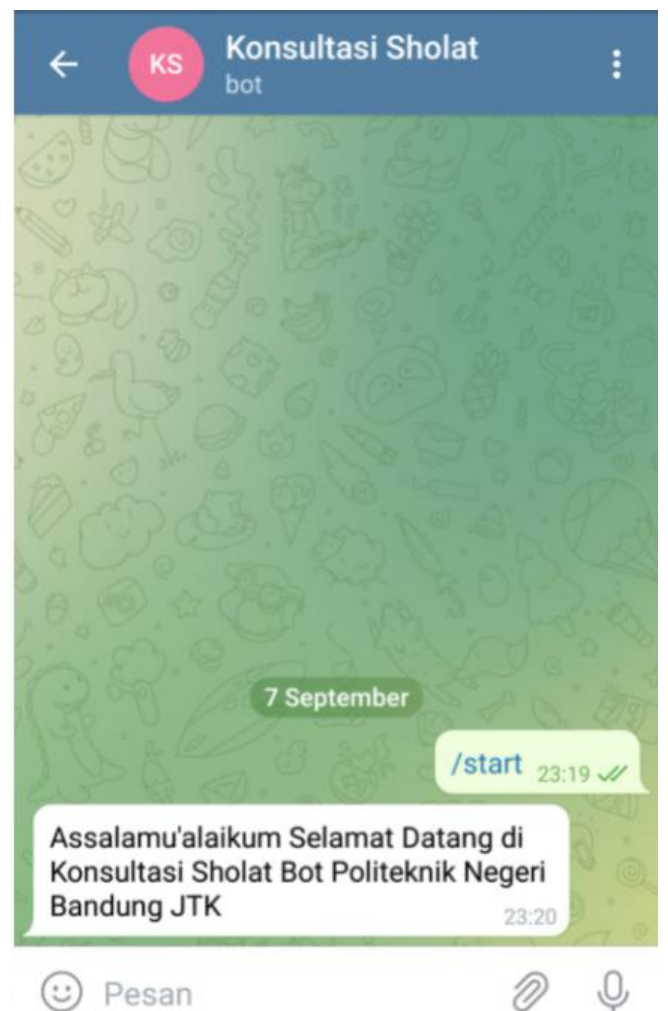

Gambar 7. Tampilan awal bot konsultasi sholat telegram

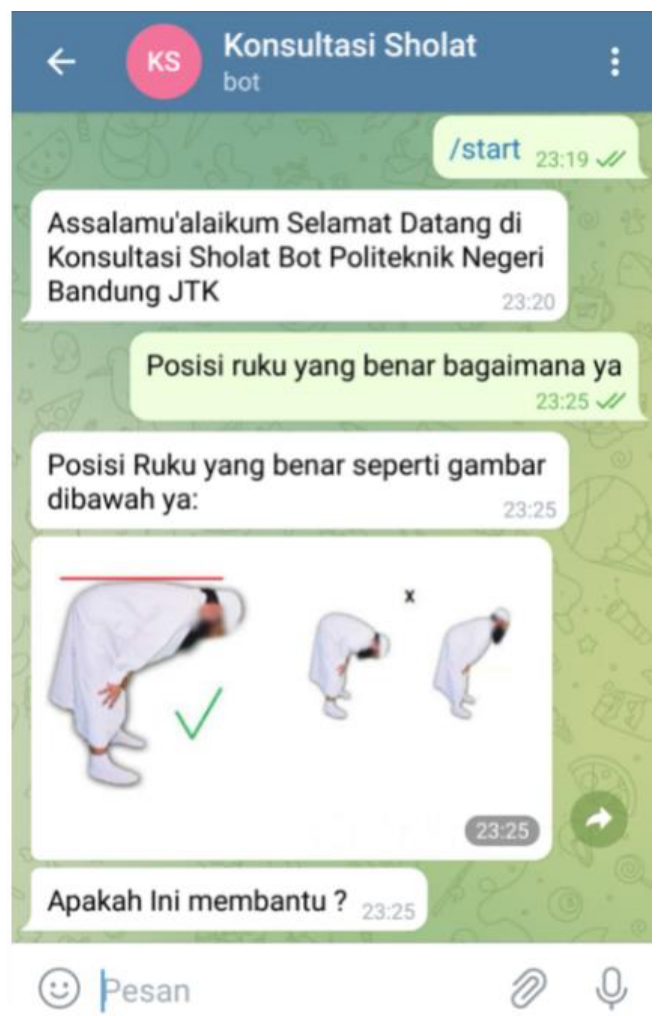

Gambar 8. Pertanyaan dari user dan jawaban dari bot 


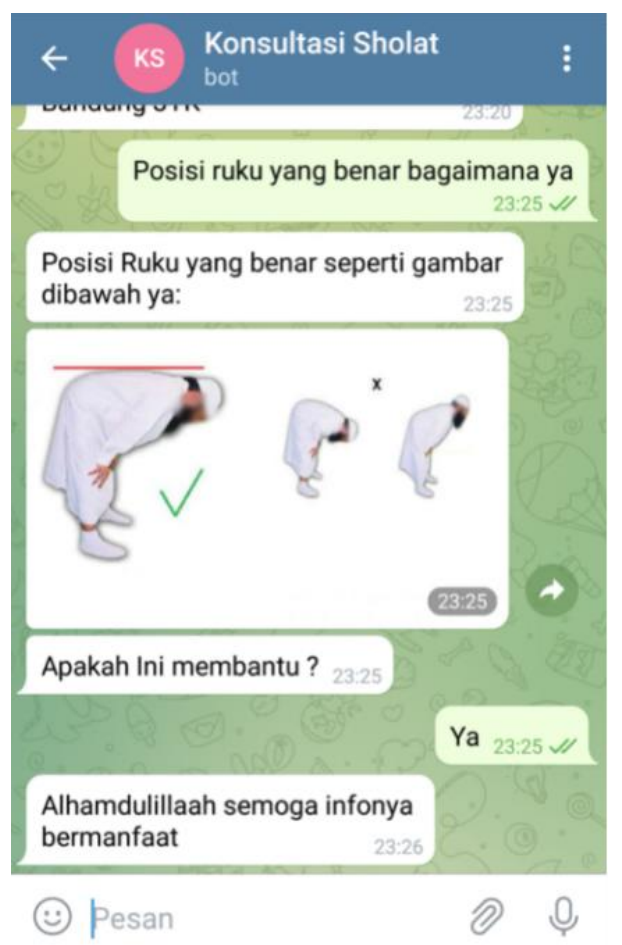

Gambar 9. Respon bot

Gambar 8 dan Gambar 9 menunjukkan bagaimana proses interaksi yang terjadi antara pengguna dengan chatbot. Pada Gambar 8 pengguna bertanya mengenai masalah seputar shalat, yaitu "Posisi ruku yang benar bagaimana ya". Respon yang diberikan oleh chatbot atas pertanyaan tersebut berupa teks "Posisi Ruku yang benar seperti gambar dibawah ya:" dan gambar posisi ruku. Selain itu, chatbot juga meminta feedback dari pengguna atas jawaban yang diberikan.

Selanjutnya Gambar 9 menunjukkan jawaban pengguna atas permintaan feedback dari chatbot yang kemudian chatbot memberikan respon atas jawaban tersebut.

Tahap pengujian sistem terdiri dari dua macam, yaitu pengujian chatbot dan pengujian accuracy. Pengujian chatbot merupakan pengujian yang dilakukan langsung pada aplikasi telegram. Sedangkan pengujian accuracy dilakukan dengan menggunakan data testyang dibagi secara acak antara train dan validasi dengan menggunakan code evaluate_on_number_of_examples.

\section{Hasil dan pembahasan}

Berikut ini merupakan hasil dari pengujian chatbot pada aplikasi telegram

Tabel 1. Hasil pengujian chatbot

\begin{tabular}{|c|c|c|c|c|}
\hline \multirow{2}{*}{ No } & \multirow{2}{*}{ Skenario } & \multicolumn{2}{|l|}{ Kriteria } & \multirow{2}{*}{ Keterangan } \\
\hline & & Sukses & Gagal & \\
\hline 1 & Handle command seperti / & & $\sqrt{ }$ & $\begin{array}{l}\text { Bot Gagal menghandle masukan yang dapat } \\
\text { berpengaruh pada code seperti / atau } \\
\text { karakter terkait code }\end{array}$ \\
\hline 2 & Pertanyaan tidak baku & $\sqrt{ }$ & & $\begin{array}{l}\text { Bot dapat menjawab masukan kalimat tidak } \\
\text { baku yang masih berkaitan dengan dataset. }\end{array}$ \\
\hline 3 & Bot Mengirim Gambar & $\sqrt{ }$ & & Bot dapat mengirim jawaban berupa gambar \\
\hline 4 & $\begin{array}{l}\text { Bot Mengirim tulisan arabic } \\
\text { font }\end{array}$ & $\sqrt{ }$ & & Bot dapat mengirimkan tulisan arabic \\
\hline 5 & Menekan tombol "Prediksi" & $\sqrt{ }$ & & $\begin{array}{l}\text { Sistem melakukan prediksi dengan } \\
\text { menggunakan Algoritma dan mengarahkan } \\
\text { user ke halaman result }\end{array}$ \\
\hline
\end{tabular}


Dari Tabel 1 diketahui bahwa interface aplikasi telegram dapat digunakan dengan baik oleh chatbot yang dikembangkan.

\section{Pengujian Respon API ChatBot}

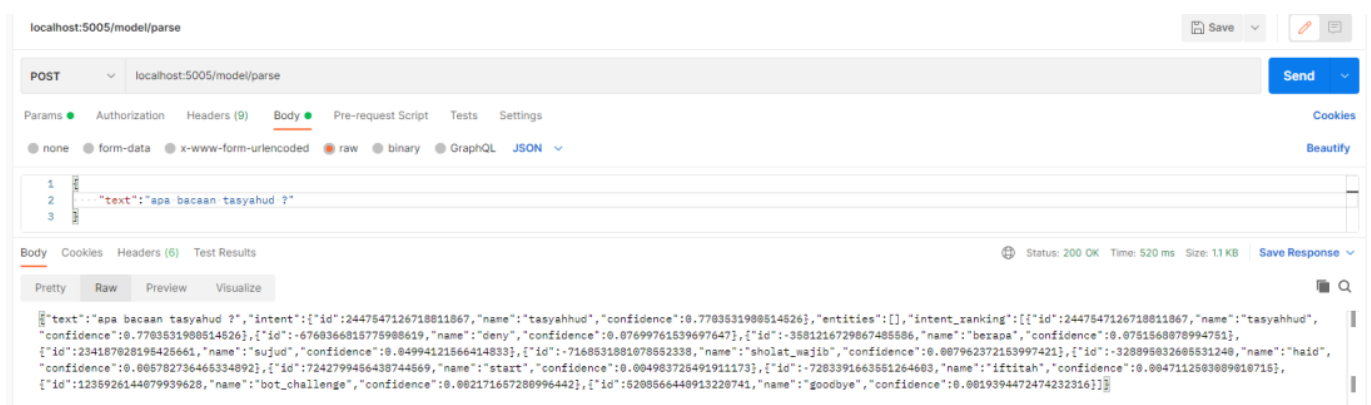

Gambar 10. Hasil pengujian respon API

Pengujian respon API chatbot dapat dilakukan dengan post ke localhost:5005/model/parse, dapat dilihat pada Gambar 10 bahwa chatbot akan memeriksa setiap intent dan memberikan skor condifence kesetiap kategori intent.

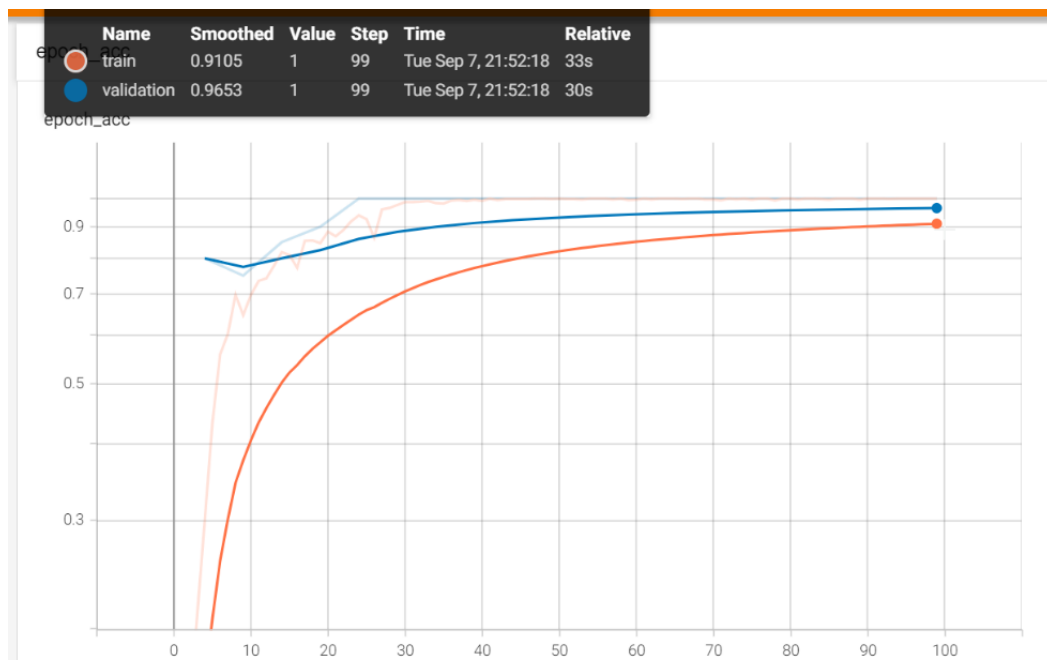

Gambar 11. Training accuracy (acc), validation accuracy (val_acc) dengan 99 step

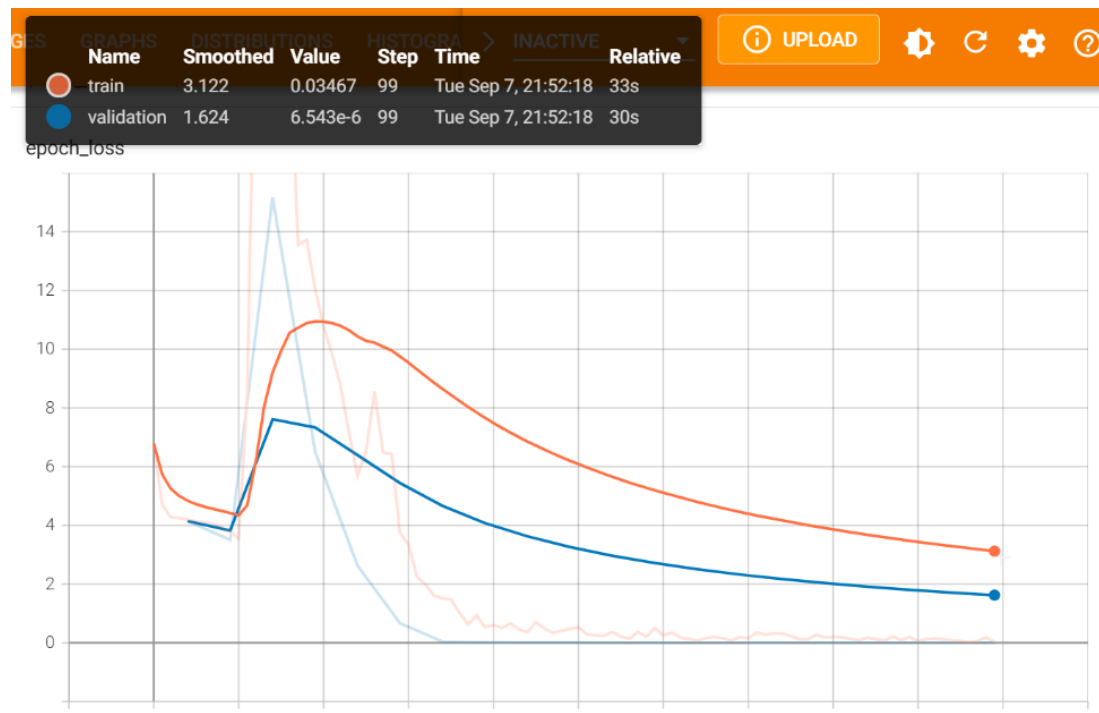

Gambar 12. training loss (loss), validation loss (val_loss) dengan 99 step 
Pada Gambar 11 dan Gambar 12 , merupakan grafik hasil Training accuracy (acc), training loss (loss), validation accuracy (val_acc), validation loss (val_loss) terhadap model yang dibuat. Perintah evaluate pada data dengan steps sebanyak 99 dari test generator menampilkan tingkat validasi akurasi adalah 0.965 dengan loss sebesar 0.000006543. Ini menunjukkan efektivitas Rasa dan model yang dibuat. Untuk meningkatkan akurasi perlu menambahkan lebih banyak data pertanyaan dan jawaban.

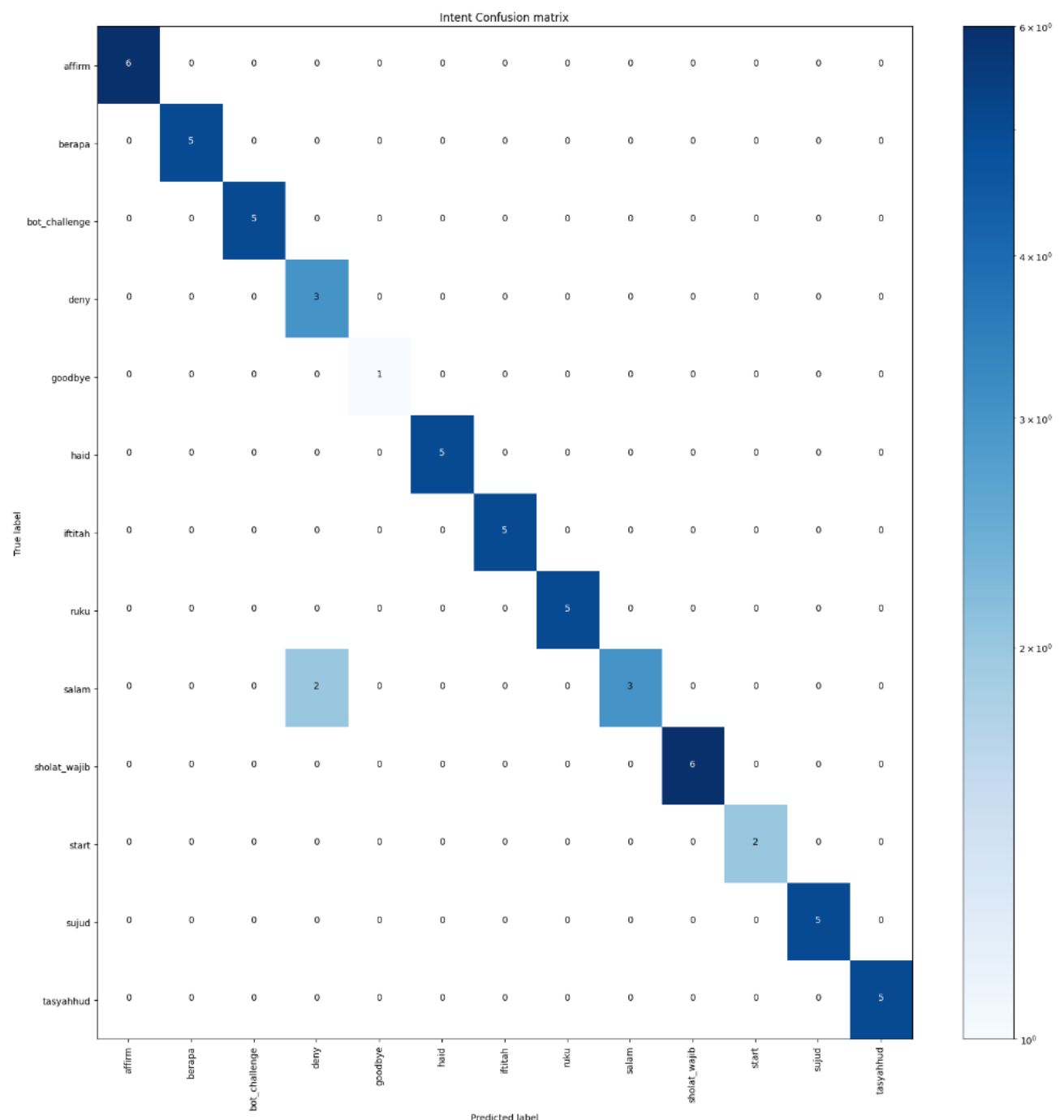

Gambar 13. Intent Confusion Matrix

Pada confusion matrix terlihat jika terdapat 2 kasus intent salam diprediksi salah. Secara keseluruhan intent untuk evaluasi dataset seluruh pertanyaan, nilai Precission 0.9692, Recall 0.9692 dan F-1 Score 0.9615.

\section{Simpulan}

Telah dibangun sebuah chatbot untuk Sistem Tanya Jawab Konsultasi Sholat Berbahasa Indonesia. Sistem dibangun dengan menerapka DIET Classifier dan Rasa melalui beberapa tahapan. Sebanyak 38 pertanyaan telah diikutkan training dan 20 pertanyaan pada pengujian aplikasi ini. Berdasarkan hasil pengujian chatbot, sistem telah berhasil menjalankan fungsi dengan baik namun masih belum bisa handle char khusus seperti ‘. Lebih jauh, dapat dilakukan penelitian lebih lanjut mengenai handle error, interactive chatbot dan menambah dataset. Adanya penambahan data akan memperbaiki model chatbot.

\section{Ucapan Terima kasih}

Penulis mengucapkan terima kasih kepada Politeknik Negeri Bandung atas fasilitas dan dukungan manajemen. Penelitian ini dilaksanakan di bawah Dana DIPA Politeknik Negeri Bandung, No. 105.80/PL.1R7/PG.00.03/2021 


\section{Daftar Pustaka}

1. S. Yoo and O. Jeong, "Auto-Growing Knowledge Graph-Based Intelligent Chatbot Using BERT." ICIC International 学会, 2020. Accessed: Sep. 07, 2021. [Online]. Available: https://doi.org/10.24507/icicel.14.01.67

2. F. H. Firmansyah, I. P. Sari, and M. Musyarofah, "Pengembangan Media Pembelajaran Interaktif Berbasis Android Untuk Pembelajaran Terbuka dan Jarak Jauh di Universitas Pendidikan Indonesia," Edsence J. Pendidik. Multimed., vol. 1, no. 2, pp. 99-108, Dec. 2019, doi: 10.17509/edsence.v1i2.21667.

3. A. G. I. Hutabarat and A. C. Padmasari, "Rancang Bangun Game Tradisional 'Tambah Satu' berbasis Platform Android," Edsence J. Pendidik. Multimed., vol. 2, no. 1, pp. 29-44, Jun. 2020, doi: 10.17509/edsence.v2i1.25028.

4. P. R. Shalih and I. Irfansyah, "Perancangan Game Berbasis Multimedia Development Life Cycle (MDLC) Tentang Tokoh Pahlawan Indonesia Masa Kini untuk Generasi Z,” Edsence J. Pendidik. Multimed., vol. 2, no. 2, pp. 83-92, Dec. 2020, doi: 10.17509/edsence.v2i2.26690.

5. H. Toba and B. Wijaya, "Implementasi Sistem Tanya Jawab Berbasis Skenario untuk Mendukung Proses Akademik dengan IBM Watson Assistant," J. Edukasi Dan Penelit. Inform. JEPIN, vol. 6, no. 2, p. 154, Aug. 2020, doi: 10.26418/jp.v6i2.40715.

6. E. N. S. C. P and I. Afrianto, "Rancang Bangun Aplikasi Chatbot Informasi Objek Wisata Kota Bandung dengan Pendekatan Natural Language Processing," Komputa J. Ilm. Komput. Dan Inform., vol. 4, no. 1, pp. 49-54, Mar. 2015, doi: 10.34010/komputa.v4i1.2410.

7. S. Triputra and F. Atqiya, "Implementation of Natural Language Processing in Seller-bot for SMEs," J. Phys. Conf. Ser., vol. 1764, no. 1, p. 012069, Feb. 2021, doi: 10.1088/1742-6596/1764/1/012069.

8. W. Suwarningsih, "Sistem Tanya Jawab Medis Berbasis Case Base Reasoning Menggunakan Semantic Role Labelling,” Disertasi Program Doktor, Institut Teknologi Bandung, 2017.

9. J. L. Kolodner, "An introduction to case-based reasoning," vol. 6, pp. 3-34, 1992, doi: https://doi.org/10.1007/BF00155578.

10. G. G. Chowdhury, "Natural language processing," Ann Rev Info Sci Tech, vol. 37, pp. 51-89, Jan. 2005, doi: https://doi.org/10.1002/aris.1440370103.

11. J. Pustejovsky and A. Stubbs, Natural Language Annotation for Machine Learning, 3rd ed. O'Reilly Media, 2013.

12. B. R. Ranoliya, N. Raghuwanshi, and S. Singh, "Chatbot for university related FAQs," 2017, pp. 15251530. doi: 10.1109/ICACCI.2017.8126057.

13. E. Ovchinnikova, Integration of World Knowledge for Natural Language Understanding. Atlantis Press, 2012. [Online]. Available: https://books.google.co.id/books?id=jfJUHOncFzkC

14. C. Olah, "Understanding LSTM Networks," Aug. 27, 2015.

15. N. K. Manaswi, "RNN and LSTM," in Deep Learning with Applications Using Python, Berkeley, CA: Apress, 2018, pp. 115-126. doi: 10.1007/978-1-4842-3516-4_9.

16. M. Saini, "Using the DIET classifier for intent classification in dialogue," medium.com, Jul. 29, 2020. https://medium.com/the-research-nest/using-the-diet-classifier-for-intent-classification-in-dialogue489c76e62804 (accessed Sep. 28, 2021).

17. T. Bunk, D. Varshneya, V. Vlasov, and A. Nichol, "DIET: Lightweight Language Understanding for Dialogue Systems," ArXiv200409936 Cs, May 2020, Accessed: Dec. 19, 2021. [Online]. Available: http://arxiv.org/abs/2004.09936 